Jolanta Kraśniewska, PhD, https:/ / orcid.org/ 0000-0003-4955-7371

The Pontifical University of John Paul II

in Krakow

\title{
The anthropology of the heart \\ as a way to ecumenical dialogue
}

\section{Antropologia serca drogą do dialogu ekumenicznego ${ }^{1}$}

\author{
https://doi.org/10.34766/fetr.v48i4.1033
}

\begin{abstract}
The article describes, taking as its main starting point the encyclical Fides et ratio, the importance of the way of thinking appropriate to the culture of the Christian East in the relationship between reason and faith. The encyclical of John Paul II has many different aspects, including the not often emphasised ecumenical and dialogical aspects. The Pope, who held Eastern (Orthodox) Christianity in high esteem and appreciated the Slavic cultural code, also positively points to this method of discovering the truth. In this context, the anthropology of the heart is particularly important (metaphysics of the heart, mysticism of the heart or spirituality of the heart), which enriches and complements the Western way of thinking and of discovering anthropological and theological truth. The anthropology of the heart also appears in the West and for this reason it has an ecumenical significance which is important for the dialogue between Catholicism and Orthodoxy.

Keywords: Fides et ratio, anthropology of the heart, spirituality of the heart, hesychasm, metaphysics of the heart, ecumenism, orthodoxy.

Abstrakt: Artykuł opisuje, wychodząc głównie od encykliki Fides et ratio, znaczenie sposobu myślenia właściwego kulturze chrześcijańskiego Wschodu w relacji rozumu i wiary. Encyklika Jana Pawła II ma wiele różnorodnych aspektów, wśród których można wymienić nie często podkreślany aspekt ekumeniczny i dialogiczny. Papież, który cenił chrześcijaństwo wschodnie (prawosławne) i doceniał słowiański kod kulturowy, wskazuje pozytywnie także na ten sposób poznania prawdy. W tym kontekście szczególnie ważna jest antropologia serca, (metafizyka serca, mistyka serca czy duchowość serca), która ubogaca i dopełnia zachodni sposób myślenia i poznania prawdy antropologicznej i teologicznej. Antropologia serca występuje również na Zachodzie i także z tej racji ma ona znaczenie ekumeniczne, ważne dla dialogu katolicyzmu z prawosławiem.
\end{abstract}

Słowa klucze: Fides et ratio, antropologia serca, duchowość serca, hezychazm, metafizyka serca, ekumenizm, prawosławie.

\section{Introduction}

From the earliest times, the concept of the heart has occupied an important place in the history, religion and culture of peoples and nations. It was a certain axis around which stories about the mystery of life, love and death were told. The heart was also identified with the concept of the soul, or a place where there was space for the realization of good and evil. Records on this subject can be found in ancient sources from Mesopotamia or the Egyptian

\footnotetext{
${ }^{1}$ Artykuł w języku polskim dostępny jest na stronie:

https://www.stowarzyszeniefidesetratio.pl/Presentations0/2021-4Kras2.pdf
} 
Book of the Dead dated to about 3000 years BCE. It is worth mentioning that for the Egyptians the heart was the centre of man, because it was the seat of intelligence, while the brain was only an auxiliary organ, which is why after death the brain was removed, and the heart was embalmed and models were even drawn up which were used for ritual functions (cf. Hoystad, 2011, 13).

The most broad and profound description of the spiritual dimension of the heart is found in the pages of the Old and New Testaments. The Bible, in its inspired verses, presents an extremely rich Judeo-Christian image of the heart, which is the place of man's encounter with God, because only He knows and penetrates the human heart - "man looks at the outward appearance, but the LORD looks at the heart." (1 Sam 16:7). The heart thinks, judges, considers the various choices, and has its own profound connections with reason and faith. Andrzej Nowicki, in his research on the symbolism of the heart, points to Origen as an author in whom the clash of biblical anthropology with philosophical anthropology is particularly visible. He perceives the heart above all as the mind, whose purity seems to be an indispensable condition for contemplation (cf. Nowicki, 2011, 45).

The spiritual dimension of the heart was shown in the teaching of the Fathers of the Church, as well as in early Christian literature, and can also be found in the teachings of the Church up to modern times. Everywhere, the heart appears as a spiritual, inner organ of man (cf. Bissi, 2017, 46-47).

In the post-Conciliar teaching of the Church, one of the few people to have explored the spirituality of the heart in its anthropological-theological dimension was the Czech Jesuit Tomáš Špidlik (1919-2010). An outstanding theologian forged in the Christian West and at the same time a world-renowned specialist in the field of Eastern spirituality (recognised as such in both the Catholic Church and the Orthodox Church), he made "spirituality of the heart" the subject of research of his theological thought (cf. Kraśniewska, 2016, 22n). In his opinion, in order to correctly interpret the heart in the Sacred Scriptures, it is necessary to pay attention to the influence of Greek thought on the biblical tradition. It seems difficult to translate the Hebrew term for this word (lev, levav) in itself containing deep and metaphorical content. It is no coincidence, according to Špidlik, that in the Septuagint the naturally speculative Greeks replaced the Hebrew lev with the Greek nous (Platonic reason, mind), as a consequence of which in Medieval Western spiritual literature, the feelings of the heart (cordis, affectus) were contrasted with the intellect and reason (intellectus, ratio). Hence the Gospel commandment to "love God with all your heart" (cf. Lk 10:27) was read by St Thomas Aquinas more as an act of will expressed by the heart, actus volontatis quae hic sinificatur per cor. The voluntary school identified the "feelings of the heart" with the decisions of the will. It was apparent that the heart was not understood in the biblical sense of the word, as the centre of the human person (cf. Špidlik, 2005, 148). 
Špidlik left an extremely extensive legacy of theological thought rooted in the CyrilloMethodian tradition and in the tradition of the Slavic East. For his merits, including in the ecumenical field, St John Paul II made him a member of the Commission for Christian Churches and raised him to the rank of cardinal. The Czech theologian was very fond of quoting the works of the Fathers of the Eastern and Western Churches, to the extent that John Meyendorff, an Orthodox theologian, claimed that Špidlik's texts "explode from the excess of quotations" (cf. Rupnik, 1999, 9).

As a professor and lecturer in patrology, standing in front of his students, he spoke in such a way that the audience had the impression that he was quoting the Greek and Syrian church fathers of the East and the West as friends with whom he had lengthy conversations yesterday (ibid.). A similar impression is felt by his readers, who in each of Špidlik's books find a modern interpretation of the words of the first Christian theologians, especially in relation to the mysticism of the heart.

It is interesting precisely that the theme of "spirituality of the heart" has often been associated with the mind (rather than with speculative reason) and faith, and in biblical anthropology and in the teaching of the Fathers of the Church, the heart appears as the centre of the human person (cf. Guillaumont, 2006, 60n).

In early Christian literature, both in Eastern and Western Christianity, as well as in the teachings of the Church up to modern times, one can also find this mystical dimension of the heart. In addition, it should be emphasised that we find the anthropology of the heart in Russian philosophy and theology, which provides an opportunity for ecumenical dialogue.

\section{Ecumenical mission in the Christian East in the view of John Paul II}

John Paul II repeatedly emphasised that the Church has always drawn from two sources of theological thought, Byzantine and Latin thought, which is why it is very important for the Church to breathe with the two lungs of the East and West, because only such a breath is fully life-giving (cf. John Paul II, 1995, paragraph 54). Ecumenism, addressed to Christian communities, has become one of the main tasks of Catholic theology and pastoral practice. The Church has opted for an ecumenical, that is, dialogical orientation of its evangelising activity, also because she recognises the inalienable bonds of fraternity that exist between Christians despite the divisions. The fundamental unity of the Church has never been completely lost. All Christians are united above all by the "sacramental bond" flowing from the sacrament of Baptism. There is a unique bond between the Catholic Church and the Orthodox Churches, which possess the true sacraments, especially by virtue of apostolic succession, the priesthood and the Eucharist (cf. Starowiejski, 2021, 283f).

The basis of our fraternity in Christ, then, is not only an affective attitude or psychological empathy, but the reality that flows from faith and the sacrament of Baptism. 
As we read in John Paul II's encyclical Ut unun sind, "Beyond the borders of the Catholic community there is no ecclesial vacuum" (John Paul II, 1995, No. 13). On the other hand, communio with Orthodoxy goes so far as to use the name "Sister Churches" (ibid., no. 55-58). This is not just a "salutation" but a basic ecumenical category of ecclesiology.

This corresponds to the Pope's idea of the new evangelisation, in which the common Christian witness of faith should be at the centre. "I feel," writes John Paul II in Orientale lumen, "that the Lord's call to work in every way to ensure that all believers in Christ will witness together to their own faith is fundamental, especially in the territories where the children of the Catholic Church - Latin and Eastern - and children of the Orthodox Churches live together in large numbers" (Starowiejski, 2021, 266).

As the eminent though controversial American Vaticanist John Allen points out, the Orthodox were John Paul II's closest brothers, with whom he felt a natural affinity (Allen, 2005 , 295). This attitude of the Pope is connected with his attitude to Russian culture.

In turn, according to Wojciech Zyzak, Karol Wojtyla as a philologist, philosopher and theologian was interested in the Christian East from the very beginning. He was deeply fascinated by its richness of language, culture, liturgical forms and spirituality. After his election as Pope, he constantly emphasised the importance of the Eastern Christian tradition for the development of the Church in Europe (cf. Zyzak, 2017).

As a philosopher, Wojtyla was interested in Russian Christian philosophical thought. Then, especially as Pope, he appreciated her contribution to building a creative relationship with Christian Revelation (ibid.). George Weigel points out that the Pope became familiar with the religious-philosophical core of Russian culture and became convinced that the Christian East has much to offer the world (cf. Terlikowski, 2016).

In the encyclical Fides et ratio, there is a direct reference to the work of Russian thinkers closest to the West, who, wanting to maintain unity with Eastern spirituality, sought an agreement with Rome (like Solovyov), or even recognised that the only cultural way forward for Russia is its occidentalisation (like Chaadaev).

In the encyclical, however, the Pope does not omit typically Orthodox theologians such as Pavel Florensky or Vladimir Lossky, who are also known in the West (ibid.).

Analysing in the encyclical Fides et Ratio the issue of the nature of faith, John Paul II opens himself to ecumenical dialogue, but also to intercultural dialogue. It is worth quoting the entirety of an important passage from the encyclical Fides et ratio, as it is very eloquent and inspiring:

"The fruitfulness of this relationship is confirmed by the experience of great Christian theologians who also distinguished themselves as great philosophers, bequeathing to us writings of such high speculative value as to warrant comparison with the masters of ancient philosophy. This is true of both the Fathers of the Church, among whom at least Gregory of Nazianzus and Saint Augustine should be mentioned, and the Medieval Doctors with the 
great triad of Saint Anselm, Saint Bonaventure and Saint Thomas Aquinas. We see the same fruitful relationship between philosophy and the word of God in the courageous research pursued by more recent thinkers, among whom I gladly mention, in a Western context, figures such as John Henry Newman, Antonio Rosmini, Jacques Maritain, Étienne Gilson and Edith Stein and, in an Eastern context, eminent scholars such as Vladimir S. Soloviev, Pavel A. Florensky, Petr Chaadaev and Vladimir N. Lossky.

Obviously other names could be cited; and in referring to these I intend not to endorse every aspect of their thought, but simply to offer significant examples of a process of philosophical enquiry which was enriched by engaging the data of faith. One thing is certain: attention to the spiritual journey of these masters can only give greater momentum to both the search for truth and the effort to apply the results of that search to the service of humanity. It is to be hoped that now and in the future there will be those who continue to cultivate this great philosophical and theological tradition for the good of both the Church and humanity." (John Paul II, 1999, no. 74)

This is a very important quote, one which is synthetic and holistic, which gives the green light to comparative research and religious dialogue. The Pope proposes integral thinking, which is always dialogical. The encyclical Fides et ratio therefore encourages dialogue. And dialogue (Greek dialogos, conversation) is: "exchange of thoughts through mutual presentation of attitudes to each other, especially such an exchange in which participants primarily want to get to know each other and pass on the intellectual and moral values they value, and the goal is to come closer to the truth together or to act together" (Dembowski, 2000, 55). It can be conducted on various levels and use various methodologies.

John Paul II wrote: "It may help, then, to turn briefly to the different modes of truth. Most of them depend upon immediate evidence or are confirmed by experimentation. This is the mode of truth proper to everyday life and to scientific research. At another level we find philosophical truth, attained by means of the speculative powers of the human intellect. Finally, there are religious truths which are to some degree grounded in philosophy, and which we find in the answers which the different religious traditions offer to the ultimate questions" (John Paul II, 1999, 30).

The basic condition for dialogue is therefore the recognition of these various forms of truth and various methodologies. The anthropology of the heart, which has great dialogical and ecumenical potential, can be such a spiritual, anthropological and methodological level. It is also worth adding that in the era of anti-humanism, human self-deification, and various psychologisms, one should return to integral anthropology, in which the heart occupies a central place as the deepest dimension in man (cf. Posacki A., Kraśniewska J. 2020, 358).

\section{Encyclical Fides et Ratio and the anthropology of the heart}


The encyclical under consideration, Fides et ratio, is about extending the concept of rationality and the theory of knowledge in theology, especially in theology of spirituality, which is what the anthropology of the heart serves. In this encyclical, Pope John Paul II believes that reflection on rationality is more and more necessary today. First of all, he is opposed to such an interpretation of reason in which it defines itself as an ultimate, and even single or absolute cognitive power that does not allow other sources of knowledge. In such a situation, we are dealing with extreme rationalism, that is, an attitude that excludes other ways of cognition, such as sense cognition or cognition through faith; the entire emotional sphere is treated as something contrary to the rational attitude, something that only disturbs it (cf. Bała, 2002-2003, 142).

And here is the place for the anthropology of the heart, so important to the theology of the Christian East, which we also encounter in the West even in the days of St. Augustine.

This theologian, one of the greatest of the Latin Church Fathers as Pope Benedict XVI called him, one who became an inspiration for Christianity and Western culture, has a lot to say also on the subject of the spirituality of the heart (Benedict XVI, 211-213). For the Bishop of Hippo, prayer is the heart's response to a thirst for God. This attention to God hiding in his heart was extraordinary and was the inspiration for all spiritual autobiographies (ibid.).

The Augustinian vision of the heart sees it as the deepest dimension of the person, calling it the interior dwelling, the unfathomable abyss and the broad tent of God. In anthropological terms, it is a centre of cognition through free will, feelings and conscience (see Galarowicz, 2017).

In the West, a similar vision of man based on the appreciation of the role of feelings in cognition was developed, among others, by Max Scheler and Dietrich von Hildebrand, who described in great detail and in many aspects the philosophical and theological foundations of the spirituality of the heart, emphasizing the value of intuitive cognition (cf. Zarzycki, 1997, 88ff).

This anthropological vision is close to the anthropology of the Eastern Church and to Russian philosophy. This does not only regard the past, but also current research and the future.

\section{The meaning of "heart" in relation to the experience of faith}

As it was noticeable in the considerations of John Paul II, he accepts various types of philosophical reflection on the relationship between reason and faith.

The anthropology of the heart is about knowing God. This is important for Christianity in the East, but it seems that it should also be more widespread in the West, because theological dialogue should affect both sides. When it comes to the Christian East, one standout aspect is the philosophical and theological reflection on the "heart", which is 
already present in the Greek Fathers of the Church, today somewhat forgotten in Western theology, or even disregarded. The issue of "heart", and especially its main form, i.e. the metaphysics of the heart (one can also speak of the mysticism of the heart or the spirituality of the heart) or the anthropology of the heart, is present in the entire Russian Orthodox culture, both in philosophy and theology. Currently, it is expressed in the search for the cognitive meaning of feelings that were to indicate the world of values. It is about the work of such Western thinkers as Max Scheler or Nicolai Hartmann, Dietrich von Hildebrand, Edyta Stein or Karol Wojtyła. It also involves the category of the experience of love (including cognition through love) as an ontological and not only psychological reality, which Dietrich von Hildebrand convincingly develops (cf. Hildebrand, 2021).

It is an excellent space for dialogue in the area of the anthropology of the heart, which can also be analysed in the language of contemporary thought. However, comparative research with Russian thought on the topic in question is not very developed yet, though it is possible and necessary in the near future. As Justyna Kroczak aptly states, "the metaphysics of the heart" is a half-philosophical, theological and mystical concept, because Orthodoxy is mainly a mystical theology , according to Vladimir Lossky (cf. Kroczak, 2013).

\section{The mysticism of the heart according to Pavel Florensky}

For many Russian theologians, philosophers, and religious writers, the heart is the ontological condition for human integrity. The ontology of the heart (and not only the metaphorical dimension of this concept) is strongly emphasised by Pavel Florensky (Florensky, 2009, 216), who among the thinkers mentioned by John Paul II had the most to say and spoke the deepest about the anthropology, spirituality and mysticism of the heart (Kroczak, 2013).

Justyna Kroczak, speaking about the originality of Pavel Florensky's heart metaphysics, reminds us that he is one of the main representatives of this trend in Russian philosophy. Its concept is based on the concepts of the Church Fathers and on the theory of Pamfil Yurkevych, who was particularly concerned with the anthropology of the heart (ibid.). The most important work in which Pavel Florensky developed the metaphysics or mysticism of the heart was Pillar and Ground of Truth (Столn и утверждение Истины, 1914) [Florensky, 2009].

In this work, Pawel Florenski divided a man into three parts: abdomen, breasts and head. Each of these parts can be developed to such an extent that a person can become a mystic (or pseudo-mystic) of the relevant organ (Florensky, 2009, 216).

The correct development of the three organs, under the direction of the one with whom "the human person is above all connected," that is, the chest, is the proper (true) mysticism. The development of any other mysticism, be it the stomach or the head, 
dangerously violates the harmony in man. For any other mysticism magnifies, and necessarily also without it, the disturbed balance of life and ultimately distorts the nature of sinful man. Hence only the mysticism of the human centre, the mysticism which, in the first place, makes a man capable of receiving grace and nourishes his interior, only such mysticism repairs a person and gives him a gradual growth.

Church mysticism is naturally the mysticism of the breast, and the heart has been considered the central part of the breast since time immemorial. If the breast is the centre of the body, then the heart is the centre of the breast. And it is the heart that has always attracted the attention of the Orthodox mysticism, says Pavel Florensky (ibid.).

\section{The contribution of Card. Tomáš Špidlik to the ecumenical spirituality of} the heart

Cardinal Tomáš Špidlik, as an ecumenical theologian and a great pioneer in the discussed topic, based his work on the Greek Church Fathers and Russian philosophers, systematising and synthesising both positions (Kraśniewska, 2016, 220n).

The anthropological theology of the Church Fathers read the mystery of God and the mystery of man in a deep connection with each other and their interpenetration. Man as Imago Dei became a particularly privileged place for God's revelation, locum rivelationis Dei. Therefore, the heart in Russian personalism is the organ that carries within itself the mystery of God's image and becomes the place of God's revelation (Špidlik, 1997, 3-4). "Just as the pupil is the contact point between the external world and the internal world, so, according to the Fathers, there must be a mysterious place in man through which God enters his life with all His wealth" (Špidlik, 2005, 149). The above sentence expresses the main content of "the spirituality of the heart". The heart "truly" is the tangent point between man and God, and at the same time the privileged place of God's abode.

Tomasz Špidlik asks the question why, in the realization of the Christian vocation of becoming an image more and more like God, it is the heart that is so important? In response to this problem, he refers to the theology of Pavel Florensky, who defines the heart as the "human centre" inherent in human nature. In his opinion, it is also indicated by the Slavic etymology of the word, where sierdce is a diminutive of the noun sriedo meaning "centre". (Florensky, 2009, 217n). For this reason, it is the heart that ensures the co-essence of the body parts, in the sense of merging what is physical and spiritual in a person (Greek homousia). Tomasz Špidlik develops this idea by emphasising that the heart reveals "the image and likeness of God", also in the sense of the relationality that man enters with God, with himself with other people, and with all creation. In this way, the broadly understood "inner life" understood as "spiritual life" is created in the heart (Kimsza, 2013, 95). 
The Czech theologian in his descriptions of the spirituality of the heart, refers not only to Christian thought, but also to other religions. He cares about the universal meaning of the heart and therefore refers to the mystical thought of Sufism, where the heart and love take centre stage (Rasool, 2002). The heart is also present in Hinduism, as mentioned by Boris Vysheslavtsev, who influenced the thought of Tomasz Špidlik. The heart can also be present in the Buddhist experience of compassion, but Tomasz Špidlik does not elaborate on this topic (cf. Nowicki, 2011, 233n). In religion, the heart can be read as particularly important for the spiritual development of a person. A culture with a place for the sacred can be helpful for people of our times who seek the truth about themselves and the world, so that they can discover it in a man hidden in the heart - hos kryptos tes kardias anthropos (cf. 1 P 3, 4).

\section{Hesychasm does not mean yoga, or possible abuse and errors.}

It is interesting that the Czech cardinal refers not only to the Eastern spiritual tradition of hesychasm, but also to yoga, when it comes to the specific heart physiology. He writes that "in yoga, great importance is attached to the location of thought, connecting it with an organ that should correspond to it in accordance with the human psychophysical structure. Different thoughts are supposed to have their "natural habitat" in certain organs. The Hesychaists maintain that prayer should focus on the heart, also in the material sense, on the breast, slightly to the left" (Špidlik, 2002, 65; 2004, 63-64).

However, for the distinctiveness and purity of Christian spirituality, an important addition must be made here. In yoga, we are dealing with an "occult biology", non-empirical, questioned by modern science (the ideology of "chakras"), unfortunately eagerly exploited by occult-esoteric traditions favouring the ideology of deification of man, which from the Christian point of view is associated with the sin of idolatry. For this reason, in Pawel Florenski and other Orthodox experts in Eastern anthropology (A. Pozow), there is a clear criticism of yoga as the opposite of the Christian tradition. It is interesting that Tomasz Špidlik quotes Pavel Florensky when he says that "the mysticism of the heart in a state of grace is a sign of the health and balance of the organism, while the false mysticism of the head (this is how Florensky describes yoga) or the stomach constantly has as its beginning or result a disease, both of the soul and the body".

It should be added, however, that Tomasz Špidlik does not fully accept the radicalism of Orthodox criticism when it comes to yoga. He also does not pay attention to the fact that the theories of yoga are most promoted by occult organizations hostile to Christianity, such as the theosophy of Helena Blavatsky (who wrote about yoga), as mentioned by Pavel Florensky.

\section{Different Views on the Reality of the Heart}


The Czech theologian looks at the spirituality of the heart from many points of view and reminds readers that the Greek Fathers, in order to illuminate the biblical view of the heart, referred to certain medical theories (cf. Špidlik, 2004, 62). Also in the hesychastic tradition, the word heart often meant not only a spiritual reality, but also a heart made of flesh, where the spirit resides in a specific physical organ. Tomasz Špidlik is aware of the dangers of a literal equivalency of the heart with the body, or with feelings, and therefore he quotes Antoine Guillaumont, who sees in such a concept the danger of "spiritual materialism", e.g. the heresy of Messalianism (ibid., 62-63).

Regarding the physiological interpretation of the heart, the Czech cardinal refers to the opinion of Antoni Bloom, bishop of eastern tradition, who, being a doctor, was also a defender of the "prayer of the heart". He tried to create a kind of synthesis of his studies on this subject (ibid.). Bishop Antoni Bloom argued that thought can be located in four places of the human body: in the anterocerebral cranial centre, in the oropharyngeal centre, in the breast, and in the heart.

The anterior cerebral cranial centre is situated between the eyebrows and corresponds to abstract thought of pure intelligence. This thought can be very intense, clear, but very unstable at the same time. Concentrating your thoughts in this place requires a lot of wilful effort, but it is tiring and results in a dispersion of energy.

The oropharyngeal thought, on the other hand, has the advantage that it loses its abstract character and enters the dynamism of life, but is still inconstant. Then the thought placed in the thoracic centre, in the centre of the breast, participates in breathing and thus acquires a more stable rhythm. But the thought located in the very heart is the most stable (Špidlik, 2002, 66; 2004, 63). Here, the cardinal adheres to an ontological or realistic, and not only metaphorical, theory of the heart, just like the quoted Pavel Florensky.

When describing the phenomenon of the heart from different angles, Tomasz Špidlik points to the wealth of its sources and concepts and thus comes closer to the phenomenological method. There are many descriptions, but they are not closed (defined, finished), because the phenomenon of the heart seems to be truly inexhaustible in its mysterious complexity and anthropological richness (cf. Špidlik, 1989, 210-221).

\section{Spirituality of the heart unites the theology of Sister Churches}

Saints Cyril and Methodius (9th century), whom John Paul II announced as copatrons of Europe, represent a special model of missions carried out in Slavic lands. In their evangelisation, they relied on the so-called "Sister Church theology", understood as striving to found particular churches that created a community of friendship and fidelity to the common apostolic tradition. 
The Czech theologian, like the Slavic apostles, adopted as the basis of evangelisation in the world the patristic thought of the Christian East, contained in the idea of the image of God in man. It proclaims that all in Christ the Lord and the Saviour are equal before the Father because they are His adoptive children. Thanks to this guiding idea, the holy brothers Cyril and Methodius undertook effective evangelisation with all respect for the ethnic and cultural identity of the Slavs. Their breaking the Church's limitation to only three languages (Hebrew, Greek, and Latin) by creating the alphabet of the Slavic language for the translation of the Bible and liturgy became (despite many difficulties) the beginning of the creation of an ecclesial and cultural space in which Sister Churches could enter the thousand-year path of their own development of spirituality and culture (cf. Kraśniewska, 2016).

Cardinal Tomasz Špidlik followed a similar path, always pointing to God as the source of beauty in the sphere of culture, and giving lectures at Catholic and Orthodox universities, always highlighting the cultural and religious richness of his listeners.

It can be said with certainty that Cardinal Tomáš Špidlik in a unique way was a continuator of Cyrillo-Methodian theology, which he had studied and promoted over the previous half-century. The central point of this theology is the "spirituality of the heart", which directly relates to "Slavic theology". The Czech cardinal drew attention to the fact that it is especially the Slavic nations that give the human heart a deep meaning, identifying it with something that is "the best in man". Meanwhile, the Christian West, speaking of the heart, has always emphasised the dimension of the mystery of suffering, the passion of Jesus and his pierced heart. The symbol of the heart was primarily a sign of the suffering of Christ, while the Christian East read the heart in terms of its spiritual dimension and in the context of relationality. And even if it was the context of love, it was also read as a love relationship between man and God. In this sense, "spirituality of the heart" also means the love of God, which, through the power of the Holy Spirit working in the temple of the human heart, transforms it until it is united with itself. For this reason, in "Slavic theology" there is a clear emphasis on the heart, the place of man's relationship with God and with other people. It is also "situated" closer to everyday life, as if inscribed in the existential dimension of the human person (cf. ibid.).

This aspect is taken up by Russian thought, which only after 1800, when Russian literature begins, begins to cultivate it and give it the meaning of Slavic thought.

\section{Spirituality of the Heart and "Spiritual Ecumenism"}

The relationship of the "spirituality of the heart" with the theology of Sister Churches (such a term was also used by John Paul II in relation to the Catholic and Orthodox Churches) is in line with the perception of the biblical meaning of the heart as the central place in man. "Spiritual ecumenism" begins not at the level of theological documents, but in 
the heart of Christians of both the Eastern and Western Tradition, in which the Holy Spirit is constantly at work and urges us to bear witness to love and unity in Christ.

It seems, therefore, that in the ecumenical field, one should come back more realistically to the theology of the first centuries, with particular emphasis on biblical anthropology, in which the "spirituality of the heart" takes a central place. Experiencing a relationship with the Triune God in one's heart can help Christians rediscover the foundations of unity while remaining in the diversity of their traditions and rites.

It seems that an interesting research topic would be focused on looking for ecumenical perspectives based on the spirituality of the heart. It would be interesting and necessary to conduct research on the heart in the context of the new evangelisation and a collaboration of theology, philosophy and culture on an anthropological and theological basis. This could be an answer to the questions tormenting modern man caught up in material existence. The heart may turn out to be a way for a modern man to return to himself. It would therefore be a specific path of re-personalization as a rediscovery of the truth about the depth of the human person (cf. Kraśniewska, 2021, 48n).

Certainly, an important research issue would also be the analysis of Cyril-Methodian spirituality, which Tomasz Špidlik dealt with in the context of ecumenism. Due to the fact that the body of Tomasz Cardinal Špidlik is buried in the Velehrad Cathedral, the Sanctuary of the Apostles of the Slavs, it would be appropriate to continue great ecumenical symposia there.

\section{Summary}

In addition to promoting forms of spiritual ecumenism and developing dialogue, John Paul II attached great importance to the forms of practical ecumenism, supported by testimonies of evangelical life, which testimonies can be called the continuation of spiritual ecumenism or the implementation of the "dialogue of conversion" (cf. no. 82).

The continuation of John Paul II's intuition and desires in the field of Eastern theology and spirituality is expressed specifically in the development of metaphysics or mysticism of the heart. This spiritual path is also important for ecumenism, and more specifically for the dialogue between Catholicism and Orthodoxy. The anthropology of the heart or the spirituality of the heart is especially important in itself, as it continues and synthesises biblical and patristic theology, a theology which is common to both traditions. It connects the theme of the unity of reason and faith in a peculiar way, but in line with the Christian tradition. Moreover, the mysticism of the heart is based on theory and practice (experience) that are common to all Christian traditions.

The Holy Father John Paul II wanted the Vatican Chapel Redemptoris Mater to be established in the Apostolic Palace, a chapel which would contain the theological synthesis 
of the unity of the Eastern and Western Church for the third millennium of Christianity. The execution of this work was entrusted to Tomasz Špidlik, who developed the guiding ideas, and to Jesuit Marco Ivan Rupnik, who interpreted them artistically with his international team of artists from the Aletti community in Rome. To illustrate the uniqueness of this work, it should be emphasised that the chapel Redemptoris Mater became a meeting place for the two apostolic traditions of Peter and Andrew. The central wall representing Heavenly Jerusalem was made by the Russian Orthodox artist Alexander Kornouchov, invited especially for this work. The mosaic painting shows the great saints of the Eastern and Western Churches sitting in groups of three. This was to reflect the idea of the Fathers of the Church who believed that the community of Christians of the Heavenly Jerusalem would be the image of the Holy Trinity in the communion of hearts, wills, and thoughts (cf. Rupnik, 2007, 17-19). For the first time in the history of the Church and art, Tomasz Špidlik united the saints of the Eastern and Western Churches, placing them seated side by side. And so, at a feast in the Kingdom of Heaven, they sit, including a group comprising: John of Damascus (monk and doctor of the Church, living in the years 657-749), Thomas Aquinas (priest, Dominican, doctor of the Church, living in the years 1225-1274), and next to them Gregory Palamas (bishop and Orthodox theologian, living in the years 1296-1359).

The remaining walls contain the most important events in the history of salvation as depicted in the Eastern and Western traditions. Referring to the interior of the Chapel Redemptoris Mater, a significant statement was made by the eminent theologian of the Orthodox Church, Olivier Clément: "We are dealing with an amazing work, a prophecy for the 21st century. The prophetic Pope has commissioned a prophetic work".

It can be clearly seen that the theological synthesis contained in the mosaics of the Chapel Redemptoris Mater includes this prophetic exhortation as well as intellectual and spiritual efforts for the unity of the Church in both Latin and Byzantine traditions. It seems that this can be done on the common ground of reason, faith and heart. Everywhere there is a Holy Spirit working in the hearts of believers. And here we can ask all Christians: Is there anything more important than discovering (reason) and experiencing (faith) the living presence of God in your own heart? It is in prayer that a Christian of the East and West can repeat, following the Psalmist, "My heart said to You, Your face, Lord, I will seek" (Ps. 27,8).

\section{Bibliography:}

Allen, J. (2005). Papież Benedykt XVI. Biografia Josepha Ratzingera, Poznań: W drodze.

Bała, M. (2002-2003). Błędne koncepcje rozumu w świetle encykliki „Fides et ratio” Jana Pawła II, Studia Gdańskie, XV-XVI, 141-151.

Benedykt XVI, (2008). Ojcowie Kościoła: od Klemensa Rzymskiego do Augustyna, Poznań: $\mathrm{W}$ drodze.

Bissi, A. (2017). Guarire il cuore, Bologna: Edizioni dell'Immacolata. 
Dembowski, B. (2000). Encyklika "Fides et ratio" i problem dialogu, Studia Philosophiae Christianae, 2 (36), 53-66.

Florenski, P. (2009). Filar i podpora Prawdy, tłum. J. Chmielewski, Warszawa: Społeczny Instytut Wydawniczy "Znak".

Galarowicz, J. (2017). Wprowadzenie do antropologii filozoficznej, Kęty: Wydawnictwo Marek Derewiecki.

Guillaumont, A. (2006). U źródeł monastycyzmu chrześsijańskiego, tom 2, tłum. S. Wirpszanka, Kraków: Wydawnictwo Benedyktynów Tyniec.

Hildebrand, D. von (2021). Istota miłości, Warszawa: Wydawnictwo Fronda.

Hoystad, O.M. (2011). Serce historia kultury i symbolu, tłum. M. Gołębiewska-Bijak, Warszawa: Bellona.

Jan Paweł II, (1995). Ut unum sint (par. 54), from: www.opoka.org.pl (accsess: 5. 12. 2021).

Jan Paweł II, (1999a). Encyklika Fides et ratio, from:

https://opoka.org.pl/biblioteka/W/WP/jan_pawel_ii/encykliki/fides_ratio_0.html (access: 7.10.2021).

Jan Paweł II, (1999b). List do Artystów, from:

https://opoka.org.pl/biblioteka/W/WP/jan_pawel_ii/listy/do_artystow_04041999. html (access: 7.10.2021).

Kimsza, R. (2013). Od obrazu do podobieństwa. Tomáša Kardynała Špidlika (1919-2010) teologia duchowości, Białystok: Oficyna Wydawnicza Politechniki Białostockiej.

Kraśniewska, J. (2016). Antropologiczno-duchowy wymiar serca w teologii duchowości Kardynała Tomáša Špidlika, Duchowość w Polsce, 18, 217-233.

Kraśniewska, J. (2016). Duchowość serca wedtug Tomáša Špidlika, nieopublikowana praca doktorska, Lublin, KUL.

Kraśniewska, J. (2021). Re-personalizacja podstawą resocjalizacji, (w:) B. Majerek, A. Domagała-Kręcioch (red.), Kategorie (nie)obecne w edukacji, 47-59, Kraków: Impuls.

Kroczak, J. (2013). Palamas and Florensky: The Metaphysics of the Heart in Patristic and Russian Philosophical Tradition, Studia Ceranea. Journal of the Waldemar Ceran Research Centre for the History and Culture of the Mediterranean Area and SouthEast Europe, 3, 69-82, https:/ / doi.org/10.18778/2084-140X.03.05.

Nowicki, A. (2011). Symbolika serca, Katowice: Księgarnia Św. Jacka.

Posacki, A., Kraśniewska, J. (2020). Pomiędzy duchem, duszą, a ciałem. Wokół antropologii integralnej Edyty Stein, (w:) M. Borowska, J. Kraśniewska, (red.), Konteksty religijności i rodziny, 333-360, Kraków: Uniwersytet Papieski Jana Pawła II w Krakowie.

Rasool, S. (2002). W strone serca. Przebudzenia na ścieżce sufich, tłum. A. Saranowicz, Jaworze: Elay.

Rupnik, M.I. (1999), Introduzione, (w:) T. Špidlik (red.), A due polmoni, Roma. 
Rupnik, M.I. (2007), Il percorso di teologia e spiritualita della cappella "Redemptoris Mater", 17-19. Rzym: Ufficio delle celebrazioni liturgiche del Sommo Pontefice.

Špidlik, T. (1977). Le coeur dans la spiritualitè orthodoxe, “Centro pro unione”, 12.

Špidlik, T. (1989). Esperienza spirituale dell'Oriente cristiano, (in:) B. Secondin, T. Goffi (eds.), Corso di spiritualità. Esperienza - sistematica - proiezione, 210-221. Brescia.

Špidlik, T. (1999). L'arte di purificare il cuore, Roma: Edizioni Lipa.

Špidlik, T. (2000). Myśl rosyjska. Inna wizja człowieka, łłum. J. Dembska, Warszawa: Wydawnictwo Księży Marianów.

Špidlik, T. (2002). Sztuka oczyszczania serca, tłum. J. Czapczyk, Poznań: W Drodze.

Špidlik, T. (2004). Il cuore e lo Spirito. La dottrina spirituale di Teofane il Recluso: Città del Vaticano.

Špidlik, T. (2005). Duchowość chrześcijańskiego Wschodu, tłum. L. Rodziewicz, Kraków: Bratni Zew.

Starowiejski, M. (2021), Nasi Bracia chrześcijanie Wschodu, Kraków: Petrus.

Terlikowski, T. (2016). Jan Pawet II wobec Rosji, from: https:/ / teologiapolityczna.pl/tomaszp-terlikowski-jan-pawel-ii-wobec-rosji/ (access: 3. 11. 2021).

Zarzycki, S.T. (1997). Dietricha von Hildebranda filozoficzno-teologiczne podstawy duchowości serca, Lublin: Redakcja Wydawnictw Katolickiego Uniwersytetu Lubelskiego.

Zyzak, W. (2017), Święty Jan Paweł II o duchowości chrześcijańskiego Wschodu, Polonia Sacra, 1 (46), 165-182. 